\title{
Review
}

\section{Regulatory T Cells, a Potent Immunoregulatory Target for CAM Researchers: The Ultimate Antagonist (I)}

\section{Aristo Vojdani and Jonathan Erde}

\author{
Immunosciences Laboratory, Inc., 8693 Wilshire Boulevard, Suite 200, Beverly Hills, CA 90211, USA
}

\begin{abstract}
Over the past decade, great interest has been given to regulatory $\mathrm{T}\left(\mathrm{T}_{\text {reg }}\right)$ cells. A vast body of evidence has shown the existence and highlighted the importance of $\mathrm{T}_{\text {reg }}$ cells in the active suppression of immune system responses. This form of immunoregulation is the dominant means utilized by the immune system to reach a harmony between reciprocal response processes in order to ensure adequate host defense with minimal host detriment. Therapeutically targeting $\mathrm{T}_{\text {reg }}$ cells is a direct and powerful means to manipulate the immune system to achieve beneficial effects on various disease pathologies, including allergy, autoimmunity and cancer, as well as the facilitation of organ transplantation. This powerful target for immunoregulation is of much concern to practitioners and researchers of complementary and alternative medicine because it allows a great deal of control and certainty in dealing with the prevalence of debilitating immune system-related disorders for which there has been little remedy outside of Western Medicine.
\end{abstract}

Keywords: immune system modulation - regulatory $\mathrm{T}$ cells $-\mathrm{T}_{\text {reg }}$

\section{Setting the Stage: Establishing the Pertinence of $T_{\text {reg }}$ Cells to CAM}

This review will familiarize complementary and alternative medicine $(\mathrm{CAM})$ researchers with regulatory $\mathrm{T}\left(\mathrm{T}_{\text {reg }}\right)$ cells and their important role in maintaining homeostasis in immune system functioning. The goal of this work is 4-fold: (i) to give an overview of the complex human immune system, (ii) to assess the methodologies for $\mathrm{T}_{\text {reg }}$ cell manipulation, (iii) to present the implications of $\mathrm{T}_{\text {reg }}$ cell manipulation for therapeutic uses, and (iv) to emphasize the relevance $T_{\text {reg }}$ cells have to CAM practitioners and researchers.

A variety of homeopathic remedies have been utilized for hundreds of years, without any scientific evidence of efficacy, for the treatment of immune system-related disorders (1). Modern technologies have afforded researchers the ability to identify a number of immunomodulatory compounds, isolated from plants and fungi, and to elucidate their mechanism of

For reprints and all correspondence: Aristo Vojdani, Immunosciences Laboratory, Inc., Section of Neuroimmunology, 8693 Wilshire Boulevard, Suite 200, Beverly Hills, CA 90211, USA. E-mail: immunsci@ix.netcom.com action (2-6). A great deal of these compounds have been shown to stimulate or suppress the immune system via direct or indirect $\mathrm{T}_{\text {reg }}$ cell modulation.

The Brazilian folk medicine, sucupira seed, which has been used for attenuation of inflammation, has shown clinical and immunomodulatory effects in collagen II-induced arthritis in mice. Suppression of B cell and CD4 T cell activation, by sucupira seed extracts, lends evidence for its usage in chronic inflammatory diseases (7). Beta-sitosterol (BSS) and sitosterolin (beta-sitosterol glucoside, BSSG) are found in leaf extracts. The combination of the two proves to have profound anti-inflammatory effects and immunomodulatory actions. Various natural products, including Ginko and Cat's Claw, contain phytosterols; however, it was found that a standardized mixture, with a ratio of $100: 1$ of sterols to sterolins, is optimal in restoring appropriate immune system responses $(1,8)$. Sucupira seed extracts and plant sterols and sterolins have been found to not only alleviate symptoms of inflammation, but more importantly, repair the underlying immune system abnormality.

Agaricus blazei Murill, an edible fungus used in traditional medicine, has stimulating immune system properties.

(C) The Author (2006). Published by Oxford University Press. All rights reserved.

The online version of this article has been published under an open access model. Users are entitled to use, reproduce, disseminate, or display the open access version of this article for non-commercial purposes provided that: the original authorship is properly and fully attributed; the Journal and Oxford University Press are attributed as the original place of publication with the correct citation details given; if an article is subsequently reproduced or disseminated not in its entirety but only in part or as a derivative work this must be clearly indicated. For commercial re-use, please contact journals.permissions@oxfordjournals.org 
Experimental results reveal that the hemicellulase-derived mycelia extract induces the expression of interleukin 12 (IL-12), a cytokine involved in the generation of $\mathrm{T}_{\mathrm{H}} 1$ cells, and the enhancement of natural killer (NK) cell activity (9). An alpha-D-glucan polysaccharide from the medicinal plant Tinospora cordifolia stimulates the $\mathrm{T}_{\mathrm{H}} 1$ pathway-associated cytokine profile. Stimulation of $\mathrm{T}$ helper cell differentiation into $\mathrm{T}_{\mathrm{H}} 1$ cells gives an added boost to cell-mediated immunity (10). The stimulation of cell-mediated immunity by both of these natural products may be useful in the successful immune defense against infection.

The attenuation of inflammation and the enhancement of cell-mediated immunity presented above are just two of several potential therapeutic means to treat disease pathology using natural products that modulate the immune system $(1,4,11)$. Myriad compounds from nature have recently been investigated as to their capabilities for immune stimulation or suppression, for usage in infection, autoimmunity, allergy and organ transplant facilitation (6) (Tables 1 and 2).

This review series will commence with an overview of the development, the actions and the interactions of the constitutive components responsible for the functioning of the human immune system.

\section{A Multifaceted Cast: The Delicate Structure and Commanding Functions of Host Defense}

The body is protected by a diverse army of cells and molecules that work in concert to ensure survival through the evolution of both innate and adaptive immune mechanisms. The ultimate target that can trigger all immune responses is an antigen, which is usually a foreign macromolecule. In the presence of antigens, different cells of the immune system initiate an elaborate biosignaling pathway which leads to the production and proliferation of appropriate $\mathrm{T}$ cells and the most efficacious host defense response $(25,26)$.

\section{Stimulated Mobilization: Initiation and Mediation of the Immune Response}

Initial immune responses to any antigen require that the antigen be recognized by a $\mathrm{T}$ lymphocyte ( $\mathrm{T}$ cell). The surface of $\mathrm{T}$ cells displays $\mathrm{T}$ cell receptors (TCRs), which bind to a complex displayed at the surface of an antigen-presenting cell (APC), which include dendritic cells (DCs) and macrophages. Two means exist for antigen recognition. For exogenous antigens, APCs engulf antigen by endocytosis or phagocytosis,

Table 1. Natural products primarily modulating immune system cells

\begin{tabular}{|c|c|c|c|}
\hline Active ingredient & Source & Mechanism of action & References \\
\hline \multirow[t]{4}{*}{ Fish oil } & \multirow[t]{4}{*}{ Fish } & Regulation of $\mathrm{T}_{\text {reg }}$ cells & \multirow[t]{4}{*}{$(12,13)$} \\
\hline & & Production of IL-10, TNF- $\alpha$ & \\
\hline & & Suppression of NF- $\kappa \mathrm{B}$ activation & \\
\hline & & Suppression of COX-2, IL-2 and IL-6 & \\
\hline \multirow[t]{5}{*}{ Curcumin (diferuloylmethane) } & \multirow[t]{5}{*}{ Turmeric (Curcuma longa) } & Activation and regulation of dendrite cells & \multirow[t]{5}{*}{$(14,15,16)$} \\
\hline & & Inhibit production of IL-1- $\beta$, IL- 6 and TNF- $\alpha$ & \\
\hline & & Inhibition of NF- $\kappa \mathrm{B}$ activation & \\
\hline & & Blocks IL-12 signaling & \\
\hline & & $\begin{array}{l}\text { Expression of } \Delta \mathrm{F} 508 \text { cystic fibrosis } \\
\text { transmembrane conductance regulator }\end{array}$ & \\
\hline Bromelain & \multirow[t]{2}{*}{ Pineapple stems } & $\begin{array}{l}\text { Blocks activation of extracellular } \\
\text { regulatory kinase- } 2 \text { in T cells }\end{array}$ & \multirow[t]{2}{*}{$(17,18)$} \\
\hline (other hydrolytic enzymes) & & Inhibition of IL-2, IFN- $\gamma$ and IL-4 expression & \\
\hline \multirow[t]{2}{*}{ Vitamin-C and vitamin-E } & \multirow[t]{2}{*}{ Citrus fruits } & Generation of $\mathrm{T}_{\text {reg }}$ cells & \multirow[t]{2}{*}{$(19)$} \\
\hline & & Inhibition of NF- $\kappa \mathrm{B}$ activation & \\
\hline
\end{tabular}

Table 2. Natural products modulating cytokine production and activation

\begin{tabular}{|c|c|c|c|}
\hline Active ingredient & Source & Mechanism of action & References \\
\hline Resveratrol & Skin of red grapes & Inhibition of NF-K $\beta$ activation & $(20)$ \\
\hline Royal jelly & Secretion by worker bees & Inhibition of TNF- $\alpha$ and IL- 6 production & $(21)$ \\
\hline$(-)$-Epigallocatechin gallate & Japanese green tea & Inhibition of TNF- $\alpha$ production & $(22)$ \\
\hline & & Inhibition of DNA damage and lipid peroxidation & \\
\hline Boswellic acid & Gum resin of Boswellia serrata tree & $\begin{array}{l}\text { Downregulation of TNF- } \alpha \text { expression } \\
\text { Inhibition of NF- } \kappa \mathrm{B} \text { signaling }\end{array}$ & (23) \\
\hline$N$-acetylcysteine & Synthetic & Inhibition of NF- $\kappa \mathrm{B}$ activation & $(24)$ \\
\hline
\end{tabular}


degrade it into fragments and display the antigenic peptides within a transmembrane class II histocompatibility molecule, located on the cell surface. These antigens may be recognized by $\mathrm{CD} 4^{+} \mathrm{T}$ cells. Antigens that are generated within a cell, e.g. viral proteins, are degraded into fragments and displayed at the cell surface within a class I histocompatibility molecule. These may be recognized by cytotoxic $\mathrm{CD}^{+} \mathrm{T}$ cells, which have the ability to destroy the infected cell.

\section{Chemokine Attraction: The Beacon for Recruitment and Organization}

Recruitment of appropriate immune system cells to the site of action is aided by chemokines, which are cytokines that attract leukocytes. Chemokines bind to chemotactic cytokine receptors (CCRs) on the plasma membrane of leukocytes. Logically, cell-mediated immune cells and humoral immune cells express different CCRs. $\mathrm{T}_{\mathrm{H}} 1$ cells and macrophages express CCR5, while $\mathrm{T}_{\mathrm{H}} 2$ cells, eosinophils and basophils express CCR3.

\section{Response Reinforcement: Bolstering and Amplifying Immune Response through $\mathbf{T}$ cell Proliferation}

In order for the immune system to mount an adequate defense, it must produce more $\mathrm{T}$ cells, through a process of differentiation and proliferation. Monocytes in peripheral tissues, upon antigen encounter, secrete monocyte growth factor, which activates monocytes to develop into macrophages. In turn, these macrophages, in the presence of bacterial antigens such as lipopolysaccharides (LPS), trigger the maturation of DCs. Matured DCs migrate into the lymph nodes to spread the carried antigen, through interactions with lymph node resident DCs. Increased concentration of bacterial antigen and cytokines in the lymph nodes, over time, stimulate activated DCs to interact with naïve helper $\mathrm{T}$ cells $\left(\mathrm{T}_{\mathrm{H}} 0\right)(27-30)$. Depending on various factors related to the immune response required, the end result of this cascade will be the differentiation of $\mathrm{T}_{\mathrm{H}} 0$ into $\mathrm{T}_{\mathrm{H}} 1, \mathrm{~T}_{\mathrm{H}} 2$ or $\mathrm{T}_{\text {reg }}$ cells, followed by clonal proliferation of that $\mathrm{T}$ cell subtype (31).

$\mathrm{T}_{\mathrm{H}} 1$ cells are responsible for cell-mediated or innate immunity, while $\mathrm{T}_{\mathrm{H}} 2$ cells are responsible for humoral or adaptive immunity. Both $\mathrm{T}_{\mathrm{H}} 1$ and $\mathrm{T}_{\mathrm{H}} 2$ cells are under the regulatory influence of $\mathrm{T}_{\text {reg }}$ cells (Fig. 1).

\section{Cell-Mediated Immunity: The Immutable Guard}

$\mathrm{T}_{\mathrm{H}} 1$ cells are $\mathrm{T}$ lymphocytes that belong to the $\mathrm{CD} 4^{+}$subset. They participate in cell-mediated immunity which is essential for controlling intracellular pathogens like viruses and certain bacteria. Antigen presentation by DCs to the TCR of premature $\mathrm{CD}^{+} \mathrm{T}_{\mathrm{H}}$ cells coupled with secretion of IL-12, initiates $\mathrm{T}_{\mathrm{H}} 1$ cell production. IL-12 stimulates $\mathrm{T}_{\mathrm{H}} 1$ cells to secrete their own lymphokines, including tumor-necrosis factor-beta (TNF- $\beta$ ) and interferon-gamma (IFN- $\gamma$ ). These cytokines stimulate macrophages and the recruitment of leukocytes to the site, resulting in inflammation. $\mathrm{T}_{\mathrm{H}} 1$ cell action together with NK cell and macrophage activity maintain a complex signaling cascade whose vital goal is the effective destruction of target cells, especially virally infected or stressed host cells (32-35) (Fig. 1). In order to reinforce the $\mathrm{T}_{\mathrm{H}} 1$ immune responses, the $\mathrm{T}_{\mathrm{H}} 2$ responses are suppressed in two ways. First, IFN- $\gamma$ and IL-12, secreted by $\mathrm{T}_{\mathrm{H}} 1$ cells, inhibit the formation of $\mathrm{T}_{\mathrm{H}} 2$ cells. Second, IFN- $\gamma$ inhibits class-switching in B cells.

\section{Humoral Immunity: The Plastic Line of Defense}

The humoral immune system affords the ability to adequately protect the host from unanticipated pathogens. This system is made possible through the generation of a plethora of receptors which can recognize a wide array of antigens.

$\mathrm{T}_{\mathrm{H}} 2$ cells are produced in a manner similar to $\mathrm{T}_{\mathrm{H}} 1$ cells, but with different paracrine stimulants/cytokines. $\mathrm{T}_{\mathrm{H}} 2$ cells provide help for B cells and are essential for antibody-mediated immunity, which is needed to control extracellular pathogens. $B$ cells have specialized receptors which bind and engulf soluble antigens through receptor-mediated endocytosis. The antigen is digested into fragments which are then displayed at the cell surface within a class II histocompatibility molecule. $\mathrm{T}_{\mathrm{H}} 2$ cells with complementary TCRs bind the B cell and secrete lymphokines that induce $\mathrm{B}$ cell differentiation into a clone of plasma cells that secrete identical antibodies. These antibodies recognize and bind to an epitope on an antigen and trigger a constructive response to the antigen (Fig. 1).

$\mathrm{T}_{\mathrm{H}} 2$ cells secrete four major lymphokines. Interleukin 4 (IL-4) stimulates class-switching in B cells to promote synthesis of $\mathrm{IgE}$ antibodies and promotes premature $\mathrm{T}_{\mathrm{H}}$ cells to enter the $\mathrm{T}_{\mathrm{H}} 2$ pathway while simultaneously inhibiting the $\mathrm{T}_{\mathrm{H}} 1$ differentiation pathway. Interleukin 5 (IL-5) recruits and activates eosinophils at the site of action. Interleukin 10 (IL-10) inhibits IL-12 production by DCs therefore adding another inhibitory mechanism to the $\mathrm{T}_{\mathrm{H}} 1$ differentiation pathway. Like IL-4, interleukin 13 (IL-13) also promotes the synthesis of IgE antibodies (36-38).

\section{Reciprocal Inhibition: Rudimentary Mechanisms of Regulation}

A balance between reciprocal responses, $T_{H} 1$ and $T_{H} 2$, is necessary for the immune system to achieve homeostasis. Each division, humoral immunity and cell-mediated immunity, has the ability to suppress the other's functioning, through inhibitory pathways. Also, there is evidence that each response is capable of self-inhibition, through negative feedback, when their respective cytokine production is high. This constitutes a system of checks-and-balances which ensures that neither type of immune response is uncontrollable. However, $\mathrm{T}_{\text {reg }}$ cells have a much broader and more dominant influence over both kinds of immune defense.

\section{Regulatory T Cells: Can a Single Cell Type Actualize Harmony?}

$\mathrm{T}_{\text {reg }}$ cells, secreting IL-10 or TGF- $\beta$, are a prevailing mediator of immunological tolerance and are responsible for 


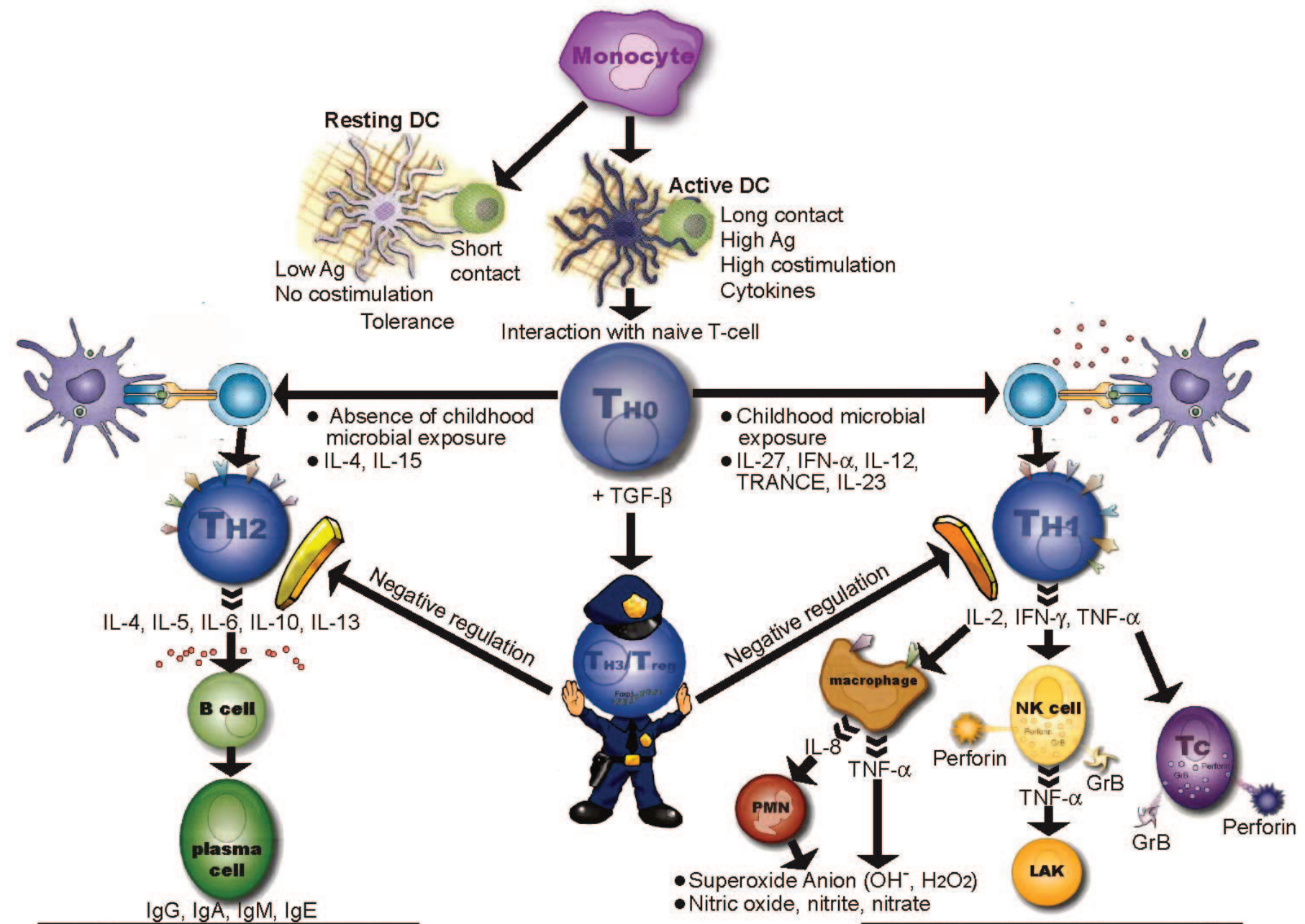

\section{Humoral Immunity}

Cell-Mediated Immunity

Figure 1. The mediators of immune system responses.

the appropriate control, via termination, of both $\mathrm{T}_{\mathrm{H}} 1$ and $\mathrm{T}_{\mathrm{H}} 2$ cell-mediated immune responses. They are the essential actor in the prevention of disease pathology related to the overaction of either response (39-44).

$\mathrm{T}_{\text {reg }}$ cells are generated from naïve $\mathrm{T}$ cells after antigenic stimulation and presentation by DCs. Various data suggests that $\mathrm{T}_{\text {reg }}$ cells represent a distinct lineage of $\mathrm{T}$ cell development (41). Characteristic expression of the inteleukin 2 receptor-alpha (IL-2Ralpha) chain (CD25) and the FOXP3 transcription factor help to differentiate $\mathrm{T}_{\mathrm{reg}}$ cells as a distinct subset of $\mathrm{CD}^{+}{ }^{+} \mathrm{T}$ cells (45).

FOXP3 (Forkhead Family Transcription Factor) is essential to $\mathrm{T}_{\text {reg }}$ cell lineage commitment, development and function. In fact, transfer of FOXP3 into naïve $T$ cells converts them into $T_{\text {reg }}$ cells. The expression of FOXP3 has been found to correlate with $\mathrm{T}_{\text {reg }}$ cells ability to suppress immune responses, indicating a possible function of FOXP3 in the $\mathrm{T}_{\text {reg }}$ cellmediated mechanism for the negative regulation of $\mathrm{T}$ cell activation (42,45-51). These developmental and functional observations of FOXP3 indicate its importance in $\mathrm{T}_{\text {reg }}$ cell function and in regulation of the immune system.

If $\mathrm{T}_{\text {reg }}$ cells could balance the immune system completely, there would be no occurrence of immune system-related disorders. The prevalence of immune system-related disorders indicates that although $\mathrm{T}_{\text {reg }}$ cells have a great deal of control, there exist factors responsible for the inappropriate development or functioning of immune responses.

\section{Immunological Development: The Hygienic Foundation of Response Strengthening}

According to the hygiene theory, at birth, the human immune system is immature and favors $\mathrm{T}_{\mathrm{H}}$ 2-like cytokine production. A wide variety of biological stimuli, ranging from helminth to viral infections, contracted from siblings or peers, can induce $\mathrm{T}_{\mathrm{H}}$ 1-like cytokine production and effectively balance 
$\mathrm{T}_{\mathrm{H}} 1$ - and $\mathrm{T}_{\mathrm{H}}$ 2-like cytokine responses and development. Children who have little contact with others or live in 'sterile' urban environments lack this $\mathrm{T}_{\mathrm{H}} 1$-like cytokine production and consequently the $\mathrm{T}_{\mathrm{H}}$ 2-like cytokine response pattern persists unchecked. A bolstering of $\mathrm{T}_{\mathrm{H}} 2$ cell development during childhood sacrifices $\mathrm{T}_{\mathrm{H}} 1$ development and puts individuals at risk for allergy later in life. The logical progression of this idea is that once the immune system develops fully, individuals will have a far greater capacity for a $\mathrm{T}_{\mathrm{H}} 2$ reponse to antigen, due to a lack of reciprocal suppression from $\mathrm{T}_{\mathrm{H}} 1$ cytokine production. This imbalance can result in an increased risk of asthma and other atopic diseases. Suppressed $\mathrm{T}_{\mathrm{H}} 1$ development and function may lead to allergic hypersensitivity, while suppressed $\mathrm{T}_{\mathrm{H}} 2$ development may result in autoimmune disorders. Thus, great interest has been focused on the biological factors that influence and determine immune system development and differentiation.

Although this view seems sound, it does not take into account the observed rise in $\mathrm{T}_{\mathrm{H}} 1$ cell-mediated autoimmune diseases in industrialized nations, nor does it address the inverse relationship between long-term helminth induced $\mathrm{T}_{\mathrm{H}} 2$ cytokine response and allergy. Since $\mathrm{T}_{\text {reg }}$ cells may be implicated in these discrepancies, researchers now postulate that $\mathrm{T}_{\text {reg }}$ cells are the key to substantiate the Hygiene Theory, which underscores the immense role $\mathrm{T}_{\text {reg }}$ cells have in proper immune system functioning (52-59).

Given that immune responses may vary according to the environment in which individuals have been raised, the importance of $\mathrm{T}_{\text {reg }}$ cells in combating this imbalance becomes apparent. In many cases it seems that $\mathrm{T}_{\text {reg }}$ cell-mediated immunomodulation is not strong enough to overcome this deficiency in development, therefore methodologies to modulate $\mathrm{T}_{\text {reg }}$ activation and functioning may prove fruitful.

\section{The Stage Has Been Set: $T_{\text {reg }}$ Cell Essentiality to the Immune System and CAM}

Harmony between the two branches of immunological host defense is imperative to human health. This review assessed the intricate tapestry of humoral and cell-mediated immune functioning, including constituents, interrelationships, feedback mechanisms, and reciprocal control. $\mathrm{T}_{\text {reg }}$ cells have been shown to maintain a crucial role in keeping the status quo through suppression of immune functioning. The wealth of cutting-edge knowledge of $\mathrm{T}_{\text {reg }}$ cell function in immune system-related disorders, coupled with substantial evidence of natural immune system modifiers, makes this cell an excellent target for investigation and application by CAM researchers. We now have a solid basis for delving into the specifics of $\mathrm{T}_{\text {reg }}$ cell action in the pathology of disease and exploring the use of $T_{\text {reg }}$ cells as a therapeutic target in the treatment of hypersensitivity, cancer, infection, autoimmunity and organ transplant facilitation. Already at the molecular level Ventura (58) has proposed that 'CAM modalities may deeply affect both the signaling and transcriptional level of cellular homeostasis. Such a perception holds promises for a new era in CAM, prompting reproducible documentation of biological responses to CAM-related strategies and compounds. To this end, functional genomics and proteomics and the comprehension of the cell signaling networks may substantially contribute to the development of a molecular evidencebased CAM'.

\section{Acknowledgements}

We greatly appreciate the contributions of Mr. Joel Bautista towards the design and illustration of the figure in this article.

\section{References}

1. Bellavite P, Conforti A, Piasere V, Ortolani R. Immunology and homeopathy. 1. Historical background. Evid Based Complement Alternat Med 2005;2:441-52.

2. Lindequist U, Niedermeyer THJ, Jülich W. The Pharmacological potential of mushrooms. Evid Based Complement Alternat Med 2005;2:285-99.

3. Inagaki N, Shibata T, Itoh T, Suzuki T, Tanaka H, Nakamura T, et al. Inhibition of IgE-dependent mouse triphasic cutaneous reaction by a boiling water fraction separated from mycelium of Phellinus linteus. Evid Based Complement Alternat Med 2005;2:369-74.

4. Naser B, Bodinet C, Tegtmeier M, Lindequist U. Thuja occidentalis (Arbor vitae): a review of its pharmaceutical, pharmacological and clinical properties. Evid Based Complement Alternat Med 2005;2:69-78.

5. Padmavathi B, Rath PC, Rao AR, Singh RP. Roots of Withania somnifera inhibit forestomach and skin carcinogenesis in mice. Evid Based Complement Alternat Med 2005;2:99-105.

6. Kaminogawa S, Nanno M. Modulation of immune functions by foods. Evid Based Complement Alternat Med 2004;1:241-50.

7. Coelho MG, Sabino KC, Dalmau SR. Immunomodulatory effects of sucupira (Pterodon pubescens) seed infusion on collagen-induced arthritis. Clin Exp Rheumatol 2004;22:213-8.

8. Bouic PJ. Sterols and sterolins: new drugs for the immune system? Drug Discov Today 2002;7:775-8.

9. Kasai H, He LM, Kawamura M, Yang PT, Deng XW, Munkanta M, et al. IL-12 production induced by Agaricus blazei fraction $\mathrm{H}(\mathrm{ABH})$ involves toll-like receptor (TLR). Evid Based Complement Alternat Med 2004;1:259-67.

10. Nair PK, Rodriguez S, Ramachandran R, Alamo A, Melnick SJ, Escalon E, et al. Immune stimulating properties of a novel polysaccharide from the medicinal plant Tinospora cordifolia. Int Immunopharmacol 2004;4:1645-59.

11. Haddad PS, Azar GA, Groom S, Boivin M. Natural health products, modulation of immune function and prevention of chronic diseases. Evid Based Complement Alternat Med 2005;2:513-20.

12. Prescott SM, Stenson WF. Fish oil fix. Nat Med 2005;11:596-8.

13. Babcock TA, Novak T, Ong E, Jho DH, Helton WS, Espat NJ. Modulation of lipopolysaccharide-stimulated macrophage tumor necrosis factor- $\alpha$ production by $\omega-3$ fatty acid is associated with differential cyclooxygenase-2 protein expression and is independent of interleukin-10. J Surg Res 2002;107:135-9.

14. Natarajan C, Bright JJ. Curcumin inhibits experimental allergic encephalomyelitis by blocking IL-12 signaling through janus kinase-stat pathway in T lymphocytes. J Immunol 2002;169:6506-13.

15. Kim GY, Kim KH, Lee SH, Yoon MS, Lee HJ, Moon DO, et al. Curcumin inhibits immunostimulatory function of dendritic cells: MAPKs and translocation of NF- $\kappa \mathrm{B}$ as potential targets. J Immunol 2005; 174:8116-24.

16. Egan ME, Pearson M, Weiner SA, Rajendran V, Rubin D, Glöckner-Pagel J, et al. Curcumin, a major constituent of tumeric, corrects cystic fibrosis defects. Science 2004;304:600-2.

17. Mynott TL, Ladhams A, Scarmato P, Engwerda CR. Bromelain, from pineapple stems, proteolytically blocks activation of extracellular regulated kinase-2 in T cells. J Immunol 1999;163:2568-75.

18. Targoni OS, Tary-Lehmann M, Lehmann PV. Prevention of murine EAE by oral hydrolytic enzyme treatment. J Autoimmun 1999;12:191-8. 
19. Tan PH, Sagoo P, Chan C, Yates JB, Campbell J, Beutelspacher SC, et al. Inhibition of NF- $\mathrm{KB}$ and oxidative pathways in human dendritic cells by antioxidative vitamins generates regulatory $\mathrm{T}$ cells. $J$ Immunol 2005; 174:7633-44.

20. Estrov Z, Shishodia S, Faderl S, Harris D, Van Q, Kantarjian HM, et al. Resveratrol blocks interleukin-1 B-induced activation of the nuclear transcription factor $\mathrm{NF}-\kappa \mathrm{B}$, inhibits proliferation, causes S-phase arrest, and induces apoptosis of acute myeloid leukemia cells. Blood 2003;102: 987-95.

21. Kohno K. Royal jelly inhibits the production of proinflammatory cytokines by activated macrophages. Biosci Biotechnol Biochem 2004;68:138-45.

22. Fujik H, Suganuma M, Okabe S, Sueoka E, Suga K, Imai K, et al. A new concept of tumor promotion by tumor necrosis factor- $\alpha$, and cancer preventive agents $(-)$-epihallocatechin gallate and green tea-a review. Cancer Detect Prev 2000;24:91-9.

23. Syrovets T, Büchele B, Krauss C, Laumonnier Y, Simmet T. Acetylboswellic acids inhibit lipopolysaccharide-mediated TNF- $\alpha$ induction in monocytes by direct interaction with IאB kinases. J Immunol 2005;174: 498-506.

24. Blackwell TS, Blackwell TR, Holden EP, Christman BW. In vivo antioxidant treatment suppresses nuclear factor- $\kappa \mathrm{B}$ activation and neutrophilic lung inflammation. J Immunol 1996;157:1630-7.

25. Seya T, Akazawa T, Tsujita T, Matsumoto M. Role of TOLL-like receptors in adjuvant-augmented immune therapies. Evid Based Complement Alternat Med. 2006;3:31-8.

26. Cooper EL. Commentary on role of TOLL-like receptors in adjuvantaugmented immune therapies by T. Seya. Evid Based Complement Alternat Med. 2006;3:133-7.

27. Kulkarni AB, Huh C, Becker D, Geiser A, Lyght M, Flanders KC, et al. Transforming growth factor- $\beta 1$ null mutation in mice causes excessive inflammatory response and early death. Proc Natl Acad Sci USA 1993;93:770-4.

28. Cederborn L, Hall H, Ivars F. $\mathrm{CD} 4{ }^{+} \mathrm{CD} 25^{+}$regulatory $\mathrm{T}$ cells down-regulate co-stimulatory molecules on antigen-presenting cells. Eur J Immunol 2000;30:1538-43.

29. Schwartz RH. Natural regulatory T cells and self-tolerance. Nat Immunol 2005;36:327-30.

30. Piccirillo C, Shevach EM. Cutting edge: control of $\mathrm{CD}^{+}$T-cell activation by $\mathrm{CD} 4{ }^{+} \mathrm{CD} 25^{+}$immunoregulatory cells. J Immunol 2002;3: $135-42$.

31. Morelli AE, Thompson AW. Dendritic cells: regulators of alloimmunity and opportunities for tolerance induction. Immunol Rev 2003;196:125-46.

32. Mossman TR, Coffman RL. TH1 and TH2 cells: different patterns of lymphokine secretion lead to different functional properties. Annu Rev Immunol 1989;7:145-73.

33. Romagnani S. Human TH1 and TH2 subsets: doubt no more. Immunol Today 1991;12:256

34. Peltz G. A role of $\mathrm{CD}^{+}{ }^{+} \mathrm{T}$-cell subsets producing a selective pattern of lymphokines in the pathogenesis of human chronic inflammatory and allergic diseases. Immunol Rev 1991;123:23.

35. Del Prete GF, De Carli M, Almerigogna F, Giudizi MC, Biagiotti R, Romagnani S. Human IL-10 is produced by both type 1 helper (Th1) and type 2 helper (Th2) T cell clones and inhibits their antigen-specific proliferation and cytokine production. J Immunol 1993;150:353-60.

36. Mossman TR, Coffman RL. Heterogeneity of cytokine secretion patterns and functions of helper T cells. Adv Immunol 1989;46:111-47.

37. Clerici M, Wynn TA, Berzofsky JA, Blatt SP, Hendrix CW, Sher A, et al. Role of interleukin-10 in T helper cell dysfunction in asymptomatic individuals infected with the human immunodeficiency virus. J Clin Invest 1994:93:768-5.

38. Swain SL, Bradley LM, Croft M, Tonkonogy S, Atkins G, Weinberg AD, et al. Helper T-cell subsets: phenotype, function and the role of lymphokines in regulating their development. Immunol Rev 1991;123: $115-44$.
39. Sakaguchi S, Sakaguchi N, Asano M, Itoh M, Toda M. Immunologic self-tolerance maintained by activated $\mathrm{T}$ cells expressing IL-2 receptor Q-chains. J Immunol 1995;155:1151-64.

40. Shevach EM. Regulatory T cells in autoimmunity. Annu Rev Immunol 2000;18:423-49.

41. Sakaguchi S. Regulatory T cells: key controllers of immunologic self-tolerance. Cell 2001;101:455-8.

42. Sakaguchi S. Naturally arising FOXP3-expressing $\mathrm{CD} 25^{+} \mathrm{CD} 4^{+}$ regulatory $\mathrm{T}$ cells in immunological tolerance to self and non-self. Nat Immunol 2005;6:345-52.

43. Essence of harmony. Nat Immunol 2005; 6:325.

44. Sakaguchi S. Naturally arising Foxp3-expressing $\mathrm{CD} 25^{+} \mathrm{CD} 4^{+}$regulatory $\mathrm{T}$ cells in immunological tolerance to self and non-self. Nat Immunol 2005;6:345-52.

45. Fonteno JD, Rudensky AY. A well adapted regulatory contrivance: regulatory $\mathrm{T}$ cell development and the forkhead family transcription factor Foxp3. Nat Immunol 2005;6:331-7.

46. Maloy KJ, Powrie F. Regulatory $\mathrm{T}$ cells in the control of immune pathology. Nat Immunol 2001;2:816-22.

47. Groux H, O’Garra A, Bigler M, Rouleau M, Antonenko S, de Vries JE, et al. A CD4+ T-cell subset inhibits antigen-specific T-cell responses and prevents colitis. Nature 1997;389:737-42.

48. Levings MK, Sangregorio R, Galbiati F, Squadrone S, de Waal Malefyt R, Roncarolo MG. IFN- $\alpha$ and IL-10 induce the differentiation of human type 1 regulatory T cells. J Immunol 2001;166:5530-9.

49. Jonuleit H, Schmitt E, Schuler G, Knop J, Enk AH. induction of interleukin-10-producing, non-proliferating $\mathrm{CD} 4^{+} \mathrm{T}$ cells with regulatory properties by repetitive stimulation with allogeneic immature dendritic cells. J Exp Med 2000;192:1213-22.

50. Dhodapkar MV, Steinman RM, Krasovsky J, Munz C, Bhardwaj N. Antigen-specific inhibition of effector T-cell function in humans after injection of immature dendritic cells. J Exp Med 2001;193:233-8.

51. Yamagiwa S, Gray JD, Hashimoto S, Horwitz DA. A role of TGF- $\beta$ in the generation and expansion of $\mathrm{CD} 4{ }^{+} \mathrm{CD} 25^{+}$regulatory $\mathrm{T}$ cells from human peripheral blood. J Immunol 2001;166:7282-9.

52. Godfrey RC. Asthma and IgE levels in rural and urban communities of the Gambia. Clin Allergy 1975;5:201-7.

53. Strachan DP. Hay fever, hygiene, and household size. Br Med J 1989;299: 1259-60.

54. Braun-Fahrlander C, Riedler J, Herz U, Eder W, Waser M, Grize L, et al. Environmental exposure to endotoxin and its relation to asthma in school-age children. N Engl J Med 2002;347:869-77.

55. McKeever TM, Lewis SA, Smith C, Collins J, Heatlie H, Frischer M, et al. Early exposure to infections and antibiotics and the incidence of allergic disease: a birth cohort study with the West Midlands General Practice Research Database. J Allergy Clin Immunol 2002;109:43-50.

56. Matricardi PM, Rosmini F, Riondino S, Fortini M, Ferrigno L, Rapicetta M, et al. Exposure to foodborne and orofecal microbes versus airborne viruses in relation to etopy and allergic asthma: epidemiological study. Br Med J 2000;320:412-7.

57. Wills-Karp M, Santeliz J, Karp CL. The germless theory of allergic disease; revisiting the hygiene hypothesis. Nat Rev Immunol 2001;1: 69-75.

58. Sudo N, Sawamura S, Tanaka K, Aiba Y, Kubo C, Koga Y. The requirement of intestinal bacterial flora for the development of an $\operatorname{IgE}$ production system fully susceptible to oral tolerance induction. $J$ Immunol 1997;159:1739-45.

59. Smit JJ, Folkerts G, Nijkamp FP. Ramp-ing up allergies: Nramp1 (Slc11a1), macrophages and the hygiene hypothesis. Trends Immunol 2004;25:342-7.

60. Ventura C. CAM and cell fate targeting: molecular and energetic insights into cell growth and differentiation. Evid Based Complement Alternat Med $2005 ; 2: 277-83$.

Received December 27, 2005; accepted January 7, 2006 


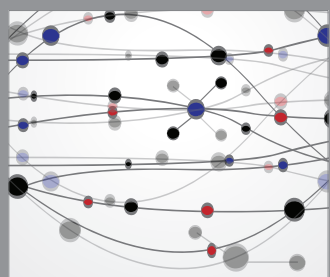

The Scientific World Journal
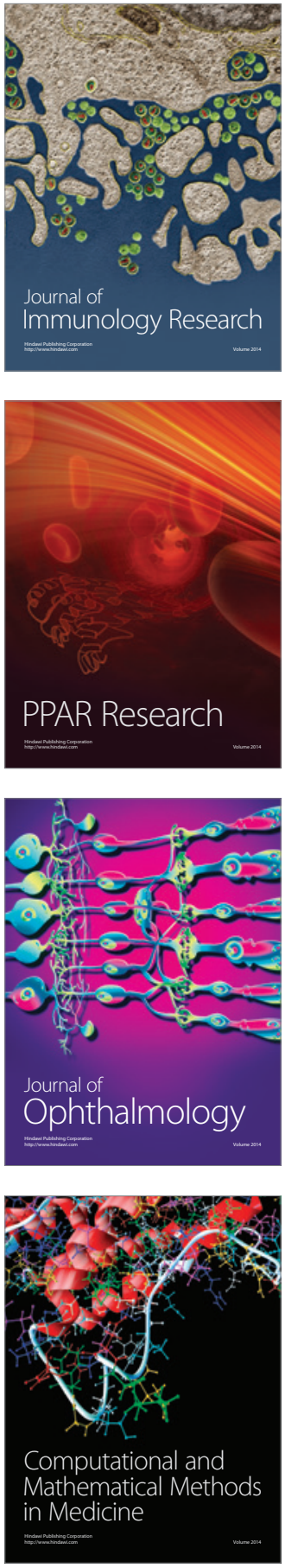

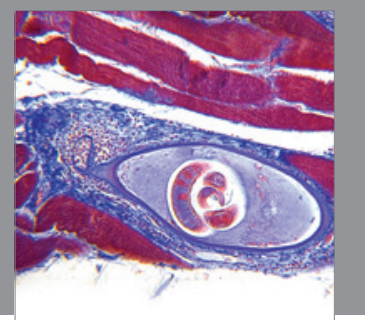

Gastroenterology

Research and Practice
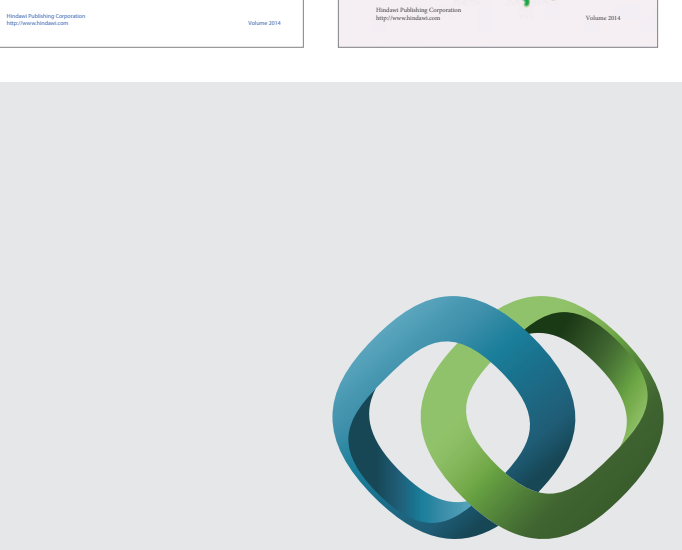

\section{Hindawi}

Submit your manuscripts at

http://www.hindawi.com
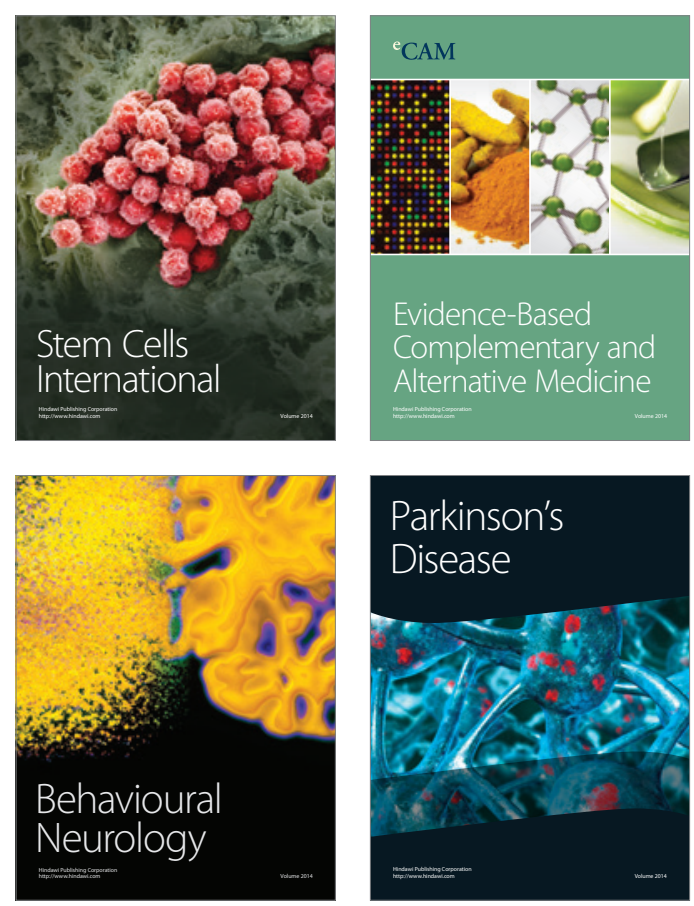

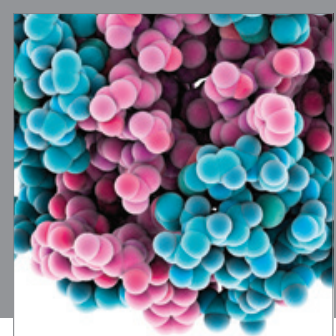

Journal of
Diabetes Research

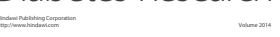

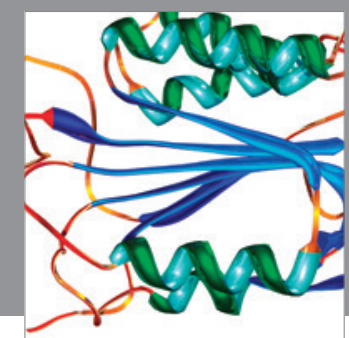

Disease Markers
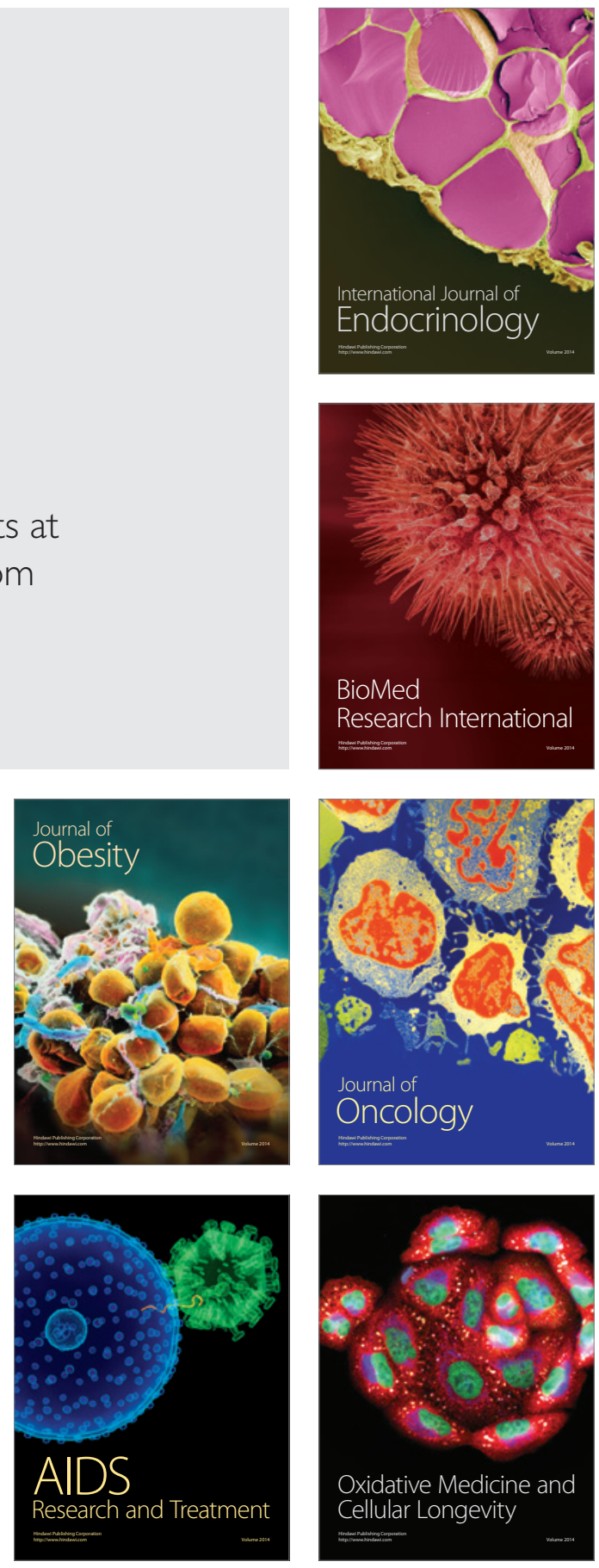